\title{
Higher Education Through The Looking Glass: One Perspective
}

\author{
ROBERT M. CLARK*
}

The main theme of the three day 1975 Annual Conference of the CSSHE in Edmonton was a consideration of four provincial reports on post-secondary education, and subsequent developments. Four speakers gave their views, and the chairmen of four provincial Commissions of Inquiry responded. The subsequent discussions at large and in four groups occupied the balance of the first day and most of the second. In the space available I shall consider only this theme, thereby omitting a summary of the sessions on the third day entitled respectively A Round Table Look at Education, and Professional Development Needs of Administrators in Higher Education.

Malcolm Taylor, an economist at York University, and President of the Society, opened the conference. He referred to the low morale of faculty in Canadian universities, and the still lower morale in American universities. He contrasted this low morale with his belief that by their nature educators are optimists. He concluded by expressing the hope that universities would more clearly than in the past formulate their mission or goals.

The four reports to which most attention was given were, in order of their publication:

1. A Choice of Futures - Report of the Commission on Education Planning Alberta 1972 - the Worth Report.

2. The Learning Society - Report of the Commission on Post-Secondary Education in Ontario - 1972 - the Wright Report.

3. Post-Secondary Education In Manitoba - Report of the Task Force on PostSecondary Education in Manitoba - 1973 - the Oliver Report.

4. Report - Royal Commission On Education, Public Services And Provincial Municipal Relations. Vol. III Education 1974 - the Graham Report.

\section{Comments of Four Panelists}

Ronald Baker, President of the University of Prince Edward Island, gave an incisive and witty comparison of these four reports. He noted that in the last two decades there have been more reports commissioned in Canada on all or some aspects of post-secondary education than on any other broad theme.

In terms of similarities of these four reports, he noted that the members of these commissions all perceive the universities to be part of a system of post-secondary education. All of the reports advocate universal accessibility to the system of postsecondary education. Some are more careful than others to emphasize that this principle does not imply that anyone should be able to take any course at any institution. Accessibility implies access from all of the provinces, as well as access from different

*Director of the Office of Academic Planning, The University of British Columbia 
levels of ability. It also implies access from all age groups, and thus a commitment to encourage life-long learning.

In varying degrees the reports advocate a wide variety of post-secondary educational programs and participatory government. All the reports emphasize accountability and public service.

The members of these commissions share a common faith in planning, more specifically a new kind of planning:

essentially derived from military planning . . it is the specification of objectives, the specification of means towards the objectives, the specification of methods of monitoring the success of the means, and . . a re-examination of the objectives.

It was clear that Ronald Baker had some apprehensions about these developments in planning, fearing that they will be implemented at the expense of participatory government and limitations on institutional autonomy through actions by government departments.

In terms of the goals of universities, little is mentioned about the quality of scholarship and research in the Alberta, Manitoba and Ontario reports. That appropriate standards will be pursued for these traditional goals, he said, is taken for granted, while the members of these three commissions write about concerns of greater interest to them such as accessibility and planning.

What is challenged is the special - some would say privileged

- position of the universities, and, much more serious a challenge

in my view, their way of governing and administering themselves so that they may achieve their ends.

The reports differ in range of topics covered, in style and in emphasis.

Were they - from the vantage point of 1975 worth the time and the cost involved? Ronald Baker gives a strongly affirmative answer to this question. He would say "yes" even if none of the recommendations and reports were adopted. The process of thinking and writing about the various alternatives was valuable alike to those who favoured innovations and to those concerned to preserve the best of what was being done.

André Côté, Professor of Philosophy at Laval University, spoke of changing emphases in higher education in Quebec. There is a new emphasis on accessibility, which involves sending faculty members out to people in various parts of the province, rather than expecting people to go to the universities and CEGEPS. There is a concern to cater for the lifetime learning interests of the people.

He added that the CEGEPS being the sole source of access to university from the school system of Quebec, the French speaking universities of the province are continuing to expand more rapidly than the English speaking universities of the country.

Gordon Campbell, Professor of Education at the University of Lethbridge presented a stimulating comparison of the development of the community college systems in the provinces of Canada. He dealt with comments on these systems in reports of the Worth Commission in Alberta, the Oliver Task Force in Manitoba, and the Wright Commission in Ontario.

In his verbal presentation he started from the proposition emphasized in the Wright, 
Worth and Oliver Reports that post-school education should "be regarded as one integrated system of further learnings." The achievement of such a system is made difficult in each province by the institutional arrangements for the governing of the colleges, and their relations to the provincial government and to the universities. It is impeded by attitudes held by the public, by students, faculty members and administrators at the colleges and universities.

One system of post-secondary education, the binary system, provides two distinctive types of educational institution - the universities and the colleges. Such a system exists in the United Kingdom, in Ontario and the Atlantic Provinces. He believes that in a binary system colleges were created to provide a type of training the universities were not designed to offer. There is a risk in such a system that it will be unduly difficult for students to transfer from a college to a university. He contrasted this binary system with the unitary system, which in Canada only exists in Quebec. In this system programs are provided for all students in Quebec who intend to go on to university as well as those who do not, or who are uncertain about their educational goals. Consequently the CEGEPS are more exciting, open, democratic and socially related than the colleges in other provinces. He added that it would be less easy to adopt such a unitary system in the other provinces. At least for Alberta he preferred the multiple purpose college system that is operating in that province.

As an example of the problems created by attitudes within colleges he said:

Left to their own devices, institutions in the west especially have tended to permit community and faculty forces to move a college toward the university model, and thus neglect essential continuing education responsibilities.

There is the risk of excessive governmental control over the colleges which will stifle or at least minimize their efforts to be creative.

Colleges in Ontario and elsewhere had the promise at their inception of contributing to a flexible, open and variegated system of education. Colleges were not to become homogenized, government managed, look-alike places. The facts suggest, however, that the colleges are being drawn ever faster into this perilous state of affairs. Despite promising efforts to decentralize, decision making power still rests mainly with central bodies. The Wright Report condemns this lack of power within individual colleges to influence major decisions. The same circumstances apply to an even greater degree in Quebec. In Manitoba and Ontario, all (in Alberta, the majority of) college personnel are civil servants; the absence of individuality and creativity in Manitoba's colleges are described by the Oliver report.

In the last section of his presentation, Gordon Campbell spoke of the concern of the colleges for their role and reputation in post secondary education. Increasingly they and, he believes, society, will not be content to acquiesce in regarding universities as in some sense "higher" and colleges as "lower" in esteem. He approves of the statement in the Wright Report.

What is needed is parity of esteem. 
He feels that more consideration from a long term viewpoint should be given to an idea recommended by the Wright Commission but overwhelmingly rejected by college students and faculty - that colleges should award their own distinctive degrees.

Professor John Dennison, of the Faculty of Education at the University of British Columbia chose to examine the four reports from the perspective of a member of society, uncommitted to post-secondary education. This led him to ask six questions:

1. Is there not a conflict between the desire for excellence in academic programs and the desire for equality of opportunity?

Each of the four reports has taken an egalitarian approach to post-secondary education, although the Graham Report did not do so to the same extent as the other three.

2. If opportunities for post-secondary education are expanded to those who could not meet present university entrance requirements, who will be responsible for the evaluation of the quality of the academic programs?

He quoted from a statement in April 1975 by the Academic Board of British Columbia, which has been replaced by the new Universities Council.

The Academic Board wishes to express its concern at the apparent increasing lack of uniformity in academic standards and curricula in ... British Columbia and with an apparent decrease in the standards of some university programs.

By a conscious policy on the part of the Department of Education, province-wide high school examinations have been phased out, and as a result there are no longer adequate guidelines to maintain uniform academic standards of high school. . .

The students most harmed by this apparent erosion of standards. are those from homes in which the parents themselves have had only limited educational opportunities, and who therefore must rely entirely on the school system for academic guidance. Of particular concern is the decreased requirement for students to demonstrate a minimum ability in written English and in mathematics.

The Academic Board also believed that one of the consequences of basing university grants on student enrolment, was to encourage universities to promote growth in numbers, even at some sacrifice in standards of admissions.

Professor Dennison agreed with the statements of the Academic Board that university entrance examinations, or examinations similar to them should be used.

The other questions on which he asked the conference participants to reflect were:

3. For which occupations is formal university education necessary?

4. If universities move in the direction of open admissions, how will the deficiencies be corrected of students who enrol with inadequate high school backgrounds in English and mathematics?

5. In an era of rising costs, how can competition among universities and colleges for students in rural areas be defended?

6. Given the divergence of viewpoints as to appropriate priorities for universities 
among faculty, among full and part time students, and among interested members of the public, what are universities doing to restate their priorities?

\section{Comments of the Chairmen of the Four Commissions}

In their remarks the four chairmen were more concerned to reflect upon the reports with which they had been associated than to comment upon the remarks of the previous speakers.

John Graham, Professor of Economics at Dalhousie University, spoke of the purposes of universities. He quoted from the Nova Scotia Report:

The universities are not trade schools or high schools. Nor are they welfare offices, research institutes or manpower centres. While a university may in some ways perform many of the functions assigned to universities, a realistic view of universities stresses that they have certain basic responsibilities in the fields of preserving, disseminating and creating knowledge. All of their activities must be subordinated to the job of ensuring that the basic goals that have come to be assigned to universities are achieved. Other goals may be pursued only where they do not conflict with the universities' reasons for existence. Universities must first ensure that they' do what they, and no other person or institution, can best do before they branch out. This they have failed to do.

He believes that in recent years universities have not emphasized what their purposes are. They have done badly in defining their goals.

He also believes that university students should pay for the benefits they receive from their education at university. Fees, he said, should cover full instructional costs; but only after provision is made for financial assistance to students with the required ability, so that no one is prevented from attending university by lack of sufficient financial resources. The top three per cent of students should have their fees paid by scholarships. These are the students whom society should be most concerned to encourage. Apart from such schol: arships generous financial assistance should be available to students, especially in their earliest years. For students in their later years primary reliance should be placed upon loans on which no interest would be charged for five years. Such loans could be repayable up to five years after graduation.

The present policy of charging fees that are far less than instructional cost has two undesirable consequences:

It provides little financial disincentive to attend university for many students who, with or without family support, can afford to be at university, but who lack the ability, or the interest, or both, to pursue the intellectual. studies that are the essence of education at these institutions.

It means that those who do not attend university are forced to subsidize those who attend, and in most cases benefit substantially from doing so. The former are likely to be in lower income groups than the latter, and no generally accepted rule of ethics supports such a redistribution of resources in society. 
Research and related studies have large elements of social benefits. Consequently it is desirable to finance them by block grants. The amount of these grants should be known several years in advance, but would be contingent upon the willingness of the universities to be part of the process of planning research priorities.

Michael Oliver, President of Carleton University, spoke of a few points he would have emphasized more strongly to his colleagues on the Manitoba Task Force if their report were being written now. He agreed with John Graham that universities should stop doing things which are or should be the responsibility of other post-secondary institutions. We should be, said he, "a lot tougher in getting university students to work or to get out. Because of financial pressures, universities are increasingly reluctant to do this."

Since the Manitoba report was written for a socialist government, the emphasis was placed on equality of access, rather than excellence of standards. He insisted, however, that these two were not incompatible. Most undergraduate work, in his opinion, could be done in institutions like CEGEPS. If this could be achieved, universities could concentrate on honours undergraduate programs or their equivalent, graduate work and research.

He referred to the advantages of descriptive reporting of the academic progress of students, as compared with the practice of providing degrees and marks. A change to such a system would be helpful in dealing with problems of transferability of credits for students moving from one university or college to another.

Walter Worth was Vice President for Planning and Development at the University of Alberta when he was appointed as a sole commissioner on educational planning in Alberta. Subsequent to the publication of the report of this commission, the Alberta Government appointed him as Deputy Minister of Advanced Education.

He stated that in the next decade Boards of Governors and the senior management of universities may be asked to be much more responsible than in the past for decisions on major university policy issues. This would imply, he said, less power for Senates and Councils in Canadian universities. A much more concerted effort by universities and governments is needed, in his opinion, to clarify the mandates and roles of the universities. He added that so far we in Canada have not been very successful. Referring to Alberta he said that his department will be moving into reviews to assess the quality of university programs.

His department is concerned to rationalize expenditures on research. In this area there has been a cosy partnership between the Federal Government and the universities. The Provincial Governments want to be included in this partnership so that their priorities will be taken into consideration. These governments will develop their own policies with regard to research.

Lastly he spoke of the need for manpower planning as well as educational planning. $\mathrm{He}$ believes that the former has not been well done in Canada. There needs to be a balance between individual aspirations of students and society's needs for people trained for various occupations. Counselling of individual students can help to achieve such a balance.

After serving for two years and ten months as Chairman of the Commission on PostSecondary Education in Ontario, Douglas Wright in 1972 became Deputy Provincial 
Secretary for Social Development in that province. In this latter role he has been concerned with health, education and community development. From both of these perspectives he commented on the four reports. Each of them, he emphasized, addressed postsecondary education not so much in terms of issues in educational policy, but rather they perceived educational institutions as instruments of social policy. The members of these commissions were reacting to forces already let loose in society. Expenditures in Canada in the 1960's in post-secondary education, health and welfare had, in differing degrees, increased at rates that could not be sustained in the long run. We are, he declared, reaching the limits of taxpayer tolerance. Public sympathy for higher education in Canada is much less than it was a few years ago. In these circumstances the political forbearance of politicians has provided a measure of protection for the universities.

For all the criticisms that have been made of post-secondary education, there has been little objective evidence of deterioration of academic standards.

Broadly speaking, the decision in Ontario to establish colleges of applied arts and technology (CAATS) was possible because the Ontario Government, with the support of federal funds, was providing enough resources to enable the universities as a group to take about as many students as they wished. Except for a very few professional programs there was no demand by the universities to accomodate more students. As a consequence there has been no tendency for the CAATS to become like universities. He regards the pluralistic model of Ontario's post-secondary education as desirable, providing a wide degree of choice for students.

\section{General Discussion}

Ted Sheffield, Professor of Higher Education at the University of Toronto, summarized the main points of concern in the general discussions as three:

-the glacial spread of government control,

-financing post secondary education,

-parity of esteem among colleges and universities.

On the first point, there appeared to be widespread concern, but little sustained discussion.

The effects of formula financing were discussed. Douglas Wright explained that the Ontario operating grant formula, which related grants directly to weighted enrolment, had been devised by the Government in its search for an acceptable method of dividing the total grant among universities. Michael Oliver replied that whatever the Government had intended, the result in practice had been that the formula had provided a powerful incentive to universities to expand enrolment. In his opinion, this led universities to compete for students and to reduce their failure rates.

John Dennison felt that the four reports had opened up a new set of expectations. Canadian universities, in their urge to expand their student enrolment, had created an enormous duplication of programs, some of which were not really justified in the public interest.

Douglas Wright agreed with John Graham that fees should cover full instructional costs. He believed that there is overwhelming evidence that it would be advantageous to give university grants to students directly, rather than to the universities. The idea had not been adopted in Canada because it was contrary to public intuition. 
On the subject of parity of esteem among universities and colleges there appeared to be considerable agreement with Ted Sheffield's comment that "the notion was a bit of nonsense," and that, as Michael Oliver said, what was needed was equal esteem for excellence in all institutions. John Dennison added that considerations of esteem arise when problems of transferability of credit for college courses at university are being considered. Universities need to accept colleges as equal partners in education.

In addition to these topics there was a lively discussion of the effectiveness of CEGEPS in Quebec. Michael Oliver praised them. Paul La Coste, Rector of the University of Montreal, expressed some criticisms of them. His chief concerns were:

Students in Quebec wanting to go to university from secondary schools are denied the freedom of choice such students have in all other provinces - of going directly to university rather than having to go for the first two years to a CEGEP. He would like to see the system modified to make this choice available. Less work is expected of students than would be required if they were taking first and second year programs at a university.

Partly because most CEGEP students do not intend to go to university, CEGEPS do not emphasize intellectual pursuits. Professional education receives less attention in CEGEPS than it would if it were available in the first two years of university. Largely as a consequence of these factors, good students spend two years at CEGEPS covering what they could easily learn in one year at a university. This is a cost both to the students and to society.

His conclusion was to advise any provincial government considering the introduction of a CEGEP system modelled on Quebec experience was: DON'T!

Michael Oliver acknowledged that there had been a downgrading of basis sciences, English and French in the CEGEPS, but said that this was a case of the system responding to social needs. Critics such as Paul La Coste had not attached sufficient importance to the social benefits of CEGEPS. These institutions have been, in his veiw, contributing to improve the high schools. In the long run CEGEPS will be very good for universities. No other province has such a good system.

At this point, I shall lay down the reporter's role, and add a few personal comments.

The difference between Paul La Coste and Michael Oliver, like some of the other differences at the conference, were essentially divergences in philosophy, rather than disagreements over facts. I noticed, for example, that Michael Oliver made no attempt to refute any of the statements of fact alleged by Paul La Coste ...

Those who attach a high priority to considerations of academic excellence would tend to conclude, as I did, that the statements of John Graham and Paul La Coste carried more conviction than those of persons with opposing viewpoints. 